\title{
Molecular and anatomical analyses reveal that Peronia verruculata (Gastropoda: Onchidiidae) is a cryptic species complex
}

\author{
Jia Jin Marc Chang ${ }^{1,4}$, Ywee Chieh Tay², Hui Ping Ang ${ }^{3}$, Karenne Phyu Phyu Tun², Loke Ming Chou², Rudolf \\ Meier $^{1,2}$, Danwei Huang ${ }^{1,2}$ \\ ${ }^{1}$ Department of Biological Sciences, National University of Singapore, Singapore 117558, Singapore \\ ${ }^{2}$ Tropical Marine Science Institute, National University of Singapore, Singapore 119227, Singapore \\ ${ }^{3}$ National Biodiversity Centre, National Parks Board, Singapore 259569, Singapore \\ ${ }^{4}$ E-mail: changjjm@u.nus.edu
}

Keywords: DNA barcoding, cytochrome c oxidase subunit I (COI), scanning electron microscopy (SEM), cryptic diversity, integrative taxonomy, Singapore

\begin{abstract}
Recent years have seen an increase in the number of studies that use DNA sequence information in addition to morphological methods, as the latter alone can be inadequate for morphologically similar, cryptic species. Marine onchidiid slugs (Mollusca: Gastropoda: Onchidiidae), which commonly inhabit intertidal environments and have a near-global distribution, comprise 11 genera and 86 described species. Singapore has 19 recorded species of onchidiids with Peronia verruculata (Cuvier, 1830) being the most abundant. Here we present mitochondrial DNA sequence data from $63 P$. verruculatalike specimens to show that they constitute two closely-related clades with distinct sequence signatures and a clear barcode gap. Intraclade distances are $0-1.8 \%$ while interclade distances range from 4.7 to $6.0 \%$. Scanning electron microscopy of internal copulation organs reveals that the two clades have distinct penial and accessory gland spine structures, which also differ in size. Using an integrative taxonomic approach, we propose that what was initially thought to be P. verruculata in Singapore, actually are two different species of Peronia.
\end{abstract}

\section{Contents}

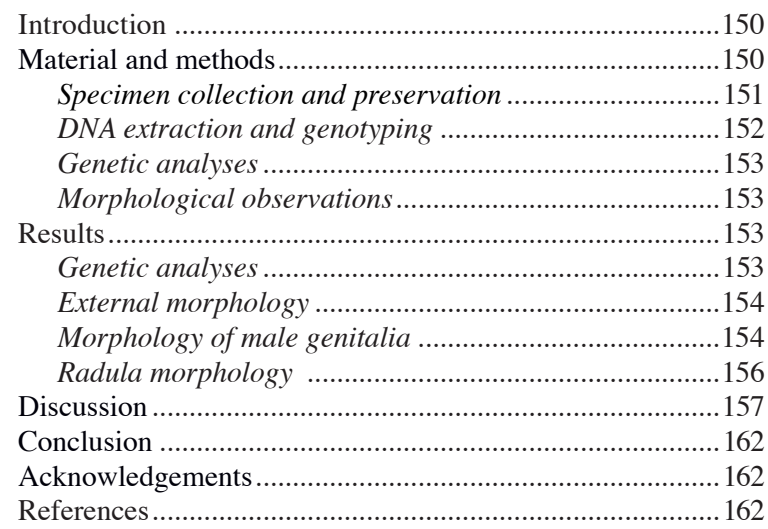

\section{Introduction}

Species delimitation is the sine qua non for biology. After all, what is defined as species often has material implications on areas such as biodiversity conservation or invasive species management (Mace, 2004; Armstrong and Ball, 2005; Bickford et al., 2007; Hendrixon et al., 2015). Molecular evidence is becoming more important for taxonomic work (Hajibabaei et al., 2007; Kress et al., 2015; Meier et al., 2016). The technique of DNA barcoding, which is predicated on the use of short, standardised DNA sequences (i.e. barcodes), has facilitated species identification in many taxonomic groups (Hebert et al., 2003, 2004; Witt et al., 2006; Moura et al., 2008). Species are also increasingly being delimited based on sequence data, a pursuit known as DNA taxonomy (Pons et al. 2006; Vogler and Monaghan, 2007). Notwithstanding the potential pitfalls associated with these DNA-based approaches (Will et al., 2005; Meier et al., 2006), the integration of molecular and morphological methods has led to numerous discoveries of cryptic species complexes (Hebert and Gregory, 2005; Bickford et al., 2007; Tan et al., 2010). In particular, DNA sequences have helped clarify the taxonomy of many gastropod species, which are notorious for being either phenotypically plastic or static; examples include Lepetodrilus (Johnson et al., 2008), Carychiidae (Weigand et al., 2011), Plakobranchus (MeyersMuñoz et al., 2016), Phyllidiidae (Stoffels et al., 2016), Rhagada (Johnson et al., 2016), Conidae (Lawler and Duda Jr., 2017), Dendronotus (Lundin et al., 2017), and Chromodorididae (Layton et al., 2018).

DNA sequences also have the potential to help with many taxonomic problems associated with gastropods 
of the family Onchidiidae. Onchidiids are shell-less, air-breathing gastropods, comprising at least 11 genera and 86 valid species (MolluscaBase, 2018). Apart from the Arctic and Antarctic, onchidiids have a nearglobal distribution, and typically inhabit the upper intertidal zone in sandy, rocky and muddy habitats; only three species are known to be terrestrial (Dayrat, 2009). Yet, until Dayrat's (2009) seminal review on Onchidiidae systematics, they have not been subject to much taxonomic research since the beginning of the $20^{\text {th }}$ century (e.g. Labbé, 1934, Starobogatov, 1976, in Dayrat, 2009). This is due to the family's complex taxonomic history; almost all species descriptions in the past were made from preserved specimens rather than live animals, thus lacking in important information that Dayrat et al. $(2016,2017)$ have shown to be crucial for species identification. Moreover, many of the characters chosen for taxonomic work either displayed high intraspecific variability or were based on reproductive structures that were difficult to access (Dayrat et al., 2016, 2017). In addition, the type specimens of many species were often lost or poorly preserved, thus rendering them of little help for clarifying species boundaries (Dayrat et al., 2016, 2017). As such, onchidiid classification remains in disarray and the nomenclatural status of most species remains unresolved, making new species descriptions nearly impossible.

These problems notwithstanding, the last decade has seen a growing body of work focused on clarifying the status of various onchidiids, such as Semperoncis montana Plate, 1893 (Dayrat, 2010a), Onchidium vaigiense Quoy and Gaimard, 1824 (Dayrat, 2010b), Hoffmannola Strand, 1932 and Onchidella Gray, 1850 in the Tropical Eastern Pacific (Dayrat et al., 2011b), Onchidium Buchannan, 1800 (Dayrat et al., 2016), Melayonchis Dayrat and Goulding, 2017 (Dayrat et al., 2017) and Platevindex mortoni Britton, 1984 (Zhang et al., 2017). The study on Onchidium by Dayrat et al. (2016) was noteworthy for being the first to apply an integrative taxonomic approach (see Dayrat, 2005) to show that distinct morphological differences observed are well-supported by molecular data in three species of Onchidium. The same approach was once again successfully applied in the delimitation of four new species in the novel genus Melayonchis (Dayrat et al., 2017). It is thus likely that such an integrative framework could also help with resolving taxonomic problems within onchidiid genera such as Peronia Fleming, 1822.

In the present study, we focus on a common intertidal onchidiid, Peronia verruculata (Cuvier,
1830). The species was initially described as Onchidium verruculatum based on specimens likely to have come from the Red Sea (Dayrat, 2009). While Cuvier (1830: 46) did not accompany that name with a description, the name is considered valid (Dayrat, 2009). It was later transferred to the genus Peronia by Labbé (1934) to distinguish species bearing dorsal gills from other onchidiids (Liow, 1997; Dayrat, 2009). Geographically, P. verruculata has been recorded from the Indo-Pacific region (Awati and Karandikar, 1948; Liow, 1997; Sun et al., 2014). Liow's (1997) study of onchidiids in Singapore ranked $P$. verruculata as the most abundant of 19 onchidiid species recorded, and it was also the only known species in Peronia (Tan and Woo, 2010). It primarily inhabits the high intertidal, preferring rocky shores and artificial seawalls. During low tides, these onchidiids emerge from their holes to graze on algae-covered rocks, producing characteristic faecal homing trails which contain directional information for navigating back to their crevices before the tide washes in (McFarlane, 1980, 1981). During high tides, they remain dormant in their inundated crevices, relying on their dorsal gills for gaseous exchange. Despite its abundance in Singapore's intertidal environment, little is known about P.verruculata, and it is thus chosen as the subject for molecular and morphological characterisation.

Here, we provide a detailed analysis of the cytochrome c oxidase subunit I (COI) gene and internal morphology to reveal unexpected division of $P$. verruculata-like slugs in Singapore into two closelyrelated clades. These results support the presence of a previously unrecognised Peronia species in Singapore, which is confirmed here based on DNA sequence and scanning electron microscopy (SEM) data.

\section{Material and methods}

\section{Specimen collection and preservation}

A total of 63 Peronia specimens were collected from the seawalls and rocky shores of nine intertidal localities across Singapore, during low spring tides between July 2015 and January 2017 (Figure 1). Seawalls are a predominant feature of Singapore's reclaimed coastline (Lai et al., 2015). They are constructed out of granite boulders and fitted to form flat, sloping surfaces facing the sea (Tan et al., 2016; fig. 2a). Conversely, rocky shores have now become a rarity, as most have been reclaimed and replaced with seawalls (Todd and 
Chou, 2005). These rocky shore environments are characterised by scattered sedimentary rock, housing communities of algae, molluscs and crustaceans (Tan et al., 2016; fig. 2b).

Specimens were identified based on Britton's (1984) and Liow's (1997) descriptions, namely: (i) opening of the male genital pore on the left of the right eye stalk (Figure 3b), (ii) presence of knobbly papillae on the dorsum bearing eyes (Figure 3c), (iii) presence of clearly differentiated gill tubercles on the posterior dorsum (Figure 3d), and (iv) green-coloured sole and hyponotum.

A piece of the hyponotum was excised from each specimen and preserved in 100\% molecular grade ethanol for molecular analyses. Voucher specimens were fixed in $10 \%$ formalin, transferred for preservation in $70 \%$ ethanol, and deposited at the Lee Kong Chian
Natural History Museum (LKCNHM, Singapore) under catalogue numbers ZRC.MOL.10094 to ZRC. MOL.10125.

The Onchidiidae collection at the LKCNHM was also examined. While the catalogue amounted to some 200 onchidiids, the vast majority of specimens were identified only as "Onchidiidae sp." and were collected from mangroves, outside the known habitat of Peronia (Liow, 1997; Dayrat et al., 2017). The rest of the collection were labelled "Onchidium verruculatum" and stored in unknown fixative that may prohibit DNA analysis, but specimens were inspected visually.

\section{DNA extraction and genotyping}

DNA was extracted from $\sim 7 \mathrm{~mm}^{2}$ of tissue material taken from the interior of the hyponotum subsample to

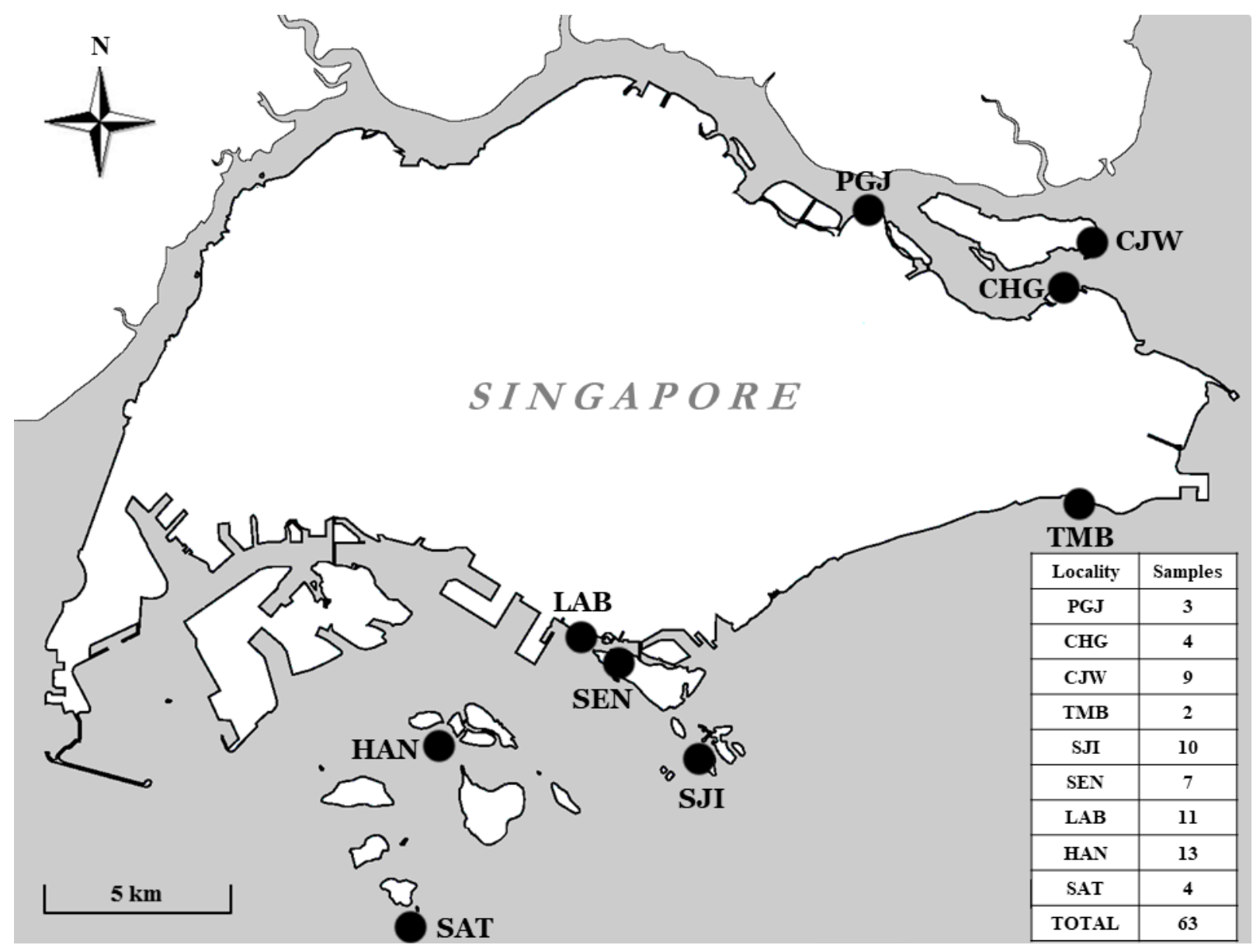

Figure 1. Sampling localities of Peronia sp. in Singapore. Localities are abbreviated as follows: Punggol Jetty (PGJ), Changi Beach (CHG), Chek Jawa Wetlands (CJW), Tanah Merah Beach (TMB), St. John's Island (SJI), Sentosa Island (SEN), Labrador Beach (LAB), Pulau Hantu (HAN) and Pulau Satumu (SAT). (Adapted from http://commons.wikimedia.org/wiki/File:Singapore_Outline.svg) 

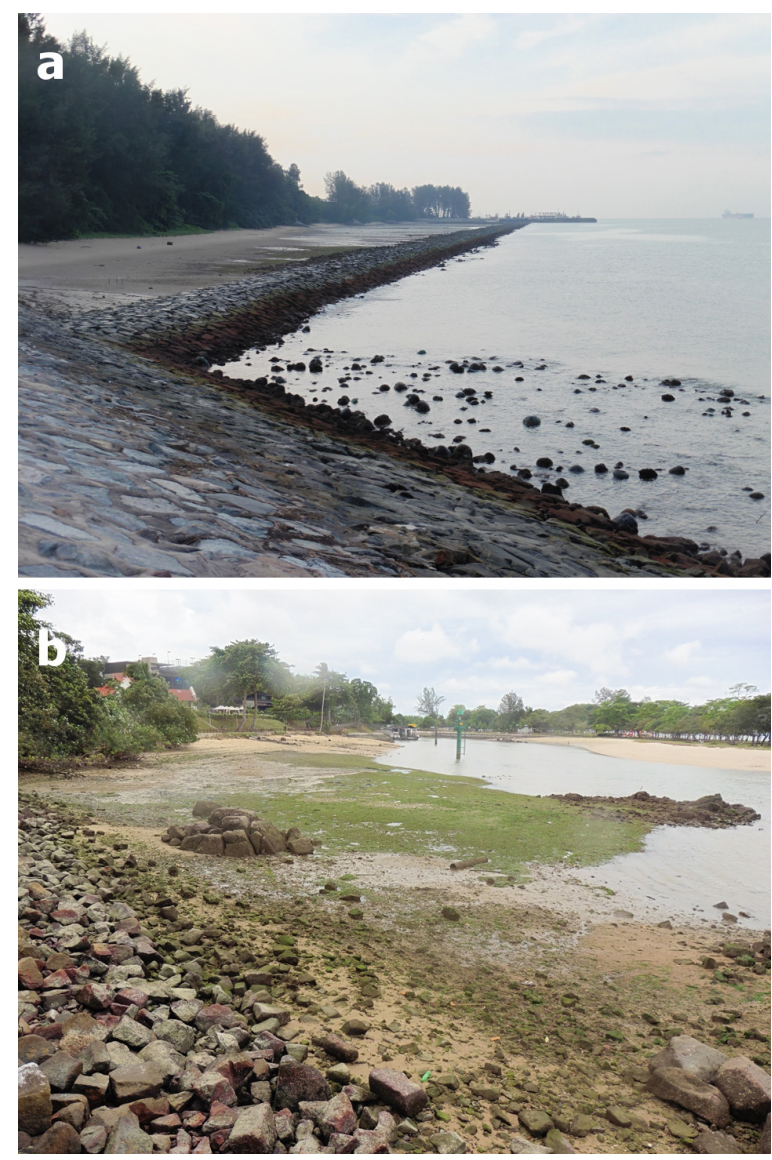

Figure 2. Sampling environments of Peronia onchidiids in Singapore: (a) seawall at Tanah Merah Beach (TMB), representative of sampling sites at St. John's Island (SJI), Labrador Beach (LAB) and Pulau Hantu (HAN); (b) rocky shore at Changi Beach (CHG), representative of sampling sites at Punggol Jetty (PGJ), Chek Jawa Wetlands (CJW), Sentosa Island (SEN) and Pulau Satumu (SAT). Photographs taken by JJM Chang.

reduce external contamination. Tissues were digested overnight using CTAB (hexadecyltrimethylammonium bromide) buffer with $0.4 \mathrm{mg}$ proteinase $\mathrm{K}$, followed by phenol: chloroform: isoamyl-alcohol $(25: 24: 1)$ for phase separation. Purified DNA pellets were eluted in $75-160 \mu \mathrm{l}$ of molecular grade water.

A partial segment of the cytochrome c oxidase subunit I (COI) gene was amplified via polymerase chain reaction (PCR) using LCO1490 and HCO2198 primers (Folmer et al., 1994). PCRs were performed in $25 \mu \mathrm{l}$ reaction mixes comprising $2 \mu \mathrm{l}$ of template DNA, $1 \times$ BioReady rTaq buffer, $0.2 \mu \mathrm{M}$ of each dNTP, $0.4 \mu \mathrm{M}$ of each primer, 1U BioReady rTaq (cat. BSA12M1, Bioflux), and $0.02 \mu \mathrm{g}$ of bovine serum albumin (BSA). The thermal cycling profile was $94^{\circ} \mathrm{C}$ for $60 \mathrm{~s} ; 35$ cycles of $94^{\circ} \mathrm{C}$ for $45 \mathrm{~s}, 48^{\circ} \mathrm{C}$ for $45 \mathrm{~s}, 72^{\circ} \mathrm{C}$ for $90 \mathrm{~s}$; and $72^{\circ} \mathrm{C}$ for 3 mins. Gene amplification was verified on $1 \%$ agarose gels. Successful amplicons were purified with SureClean Plus (Bioline) and sequenced using the BigDye Terminator v3.1 (Applied Biosystems) in a 3730xl DNA Analyzer (Thermo Fisher Scientific), following manufacturers' instructions.

Chromatograms were verified using Geneious v.10.1.3 (Kearse et al., 2012). Sequences were translated to check for stop codons and deposited with GenBank under the accession numbers MH002545MH002607.

\section{Genetic analyses}

For genetic distance analysis, we added Peronia spp. 1-6 sequences from Dayrat et al. (2011a) to our 63 sequences, for a total of 69 sequences. Following alignment using MAFFT v.7.311 under the default 'auto' parameters (Katoh et al., 2002; Katoh and Toh, 2008; Katoh and Standley, 2013), MEGA 7 (Kumar et al., 2016) was used to compute uncorrected p-distances amongst the 69 COI sequences. Uncorrected p-distance was chosen as opposed to other model-based distance methods like Kimura2-parameter (K2P) because the latter have been shown to artificially inflate interspecific distances (Srivathsan and Meier, 2012). These 69 sequences were then consolidated together with 207 publicly available onchidiid sequences from GenBank (Dayrat et al., 2011a, 2016; White et al., 2011; Cumming, 2013; Layton et al., 2014; Liu et al., 2014; Sun et al., 2014; Zhou et al., 2016) in Mesquite 3.20 (Maddison and Maddison, 2017), for a total of 276 sequences. Alignments were performed again using MAFFT, yielding a 998-bp data matrix (without gaps and stop codons) for phylogenetic analysis.

We applied maximum likelihood (ML), Bayesian, as well as maximum parsimony (MP) tree reconstructions, with Sarasinula linguaeformis (HQ660055.1) and Vaginulus taunaisii (HQ660056.1) as outgroups (Dayrat et al., 2011a). First, ML trees were inferred using RAxML 8.0.9 (Stamatakis, 2006, 2014) under the default GTRGAMMA model and 50 random starting trees. Node supports were quantified using 1,000 replicates of standard bootstrapping (Stamatakis et al., 2008). Second, for Bayesian analyses, a model of molecular evolution was chosen from a list of 24 using Akaike Information Criterion (AIC) as implemented in jModelTest 2.1.10 (Darriba et al., 2012). Bayesian inferences were performed 
using the GTR + I + G model in MrBayes 3.2.2 (Ronquist et al., 2012). Four Markov chains Monte Carlo (MCMC) of 9,000,000 generations were implemented in two runs, logging one tree per 100 generations. We employed Tracer 1.6 (Rambaut et $a l ., 2014)$ to evaluate MCMC convergence between the runs, and discarded the first 10,001 trees as burnin. Lastly, MP tree searches were performed in TNT 1.1 (Goloboff et al., 2008), using 1,000 replications comprising 100 cycles of tree fusing, drifting and ratcheting, followed by 1,000 bootstrap replicates (gaps were treated as missing).

\section{Morphological observations}

All specimen observations and excisions were made under Leica S8 APO or M205C stereo microscopes. Measurements for each specimen comprised number of dorsal eyes, and Labbé's (1934) ratio of hyponotum $(\mathrm{H})$ to sole $(\mathrm{S})$ width.

Following precedents set by contemporary onchidiid studies (Dayrat 2010a, 2010b; Dayrat et al., 2011b, 2016, 2017; Zhang et al., 2017), the radula and male reproductive organs were targeted for SEM. These structures were prioritised as they have been shown to be the most informative traits for onchidiid systematics (Britton, 1984). Radulae were cleaned in $10 \% \mathrm{NaOH}$ for $3-4$ days, rinsed in distilled water for 3-4 days, and finally sputter-coated with gold before examination under a JSM-6510LV SEM (JEOL
Ltd.). The penis and the accessory gland spines were dehydrated in $100 \%$ ethanol before sputter coating.

\section{Results}

\section{Genetic analyses}

Our analyses of 276 onchidiid COI sequences recover two separate clades nested within Peronia that contain all 63 Peronia sequences from Singapore. Each of the clades are strongly supported by Bayesian and MP, whereas ML bootstrap support is fairly low (Figure 4). Of these sequences from Singapore, 30 form a monophyletic group together with the sequence labelled "Peronia sp. 2" in GenBank (Accession number: HQ660044.1; Figure 4). The remaining 33 form a separate distinct clade on its own, with no match above $95 \%$ to any GenBank sequence, but this clade is nevertheless closely related to $P$. verruculata (Figure 4). Henceforth, we refer to the former clade as Peronia sp. 2 sensu Dayrat et al. (2011a), while the latter clade is referred to as the Singapore clade. Overall, relationships between the Peronia clades mirror those in Dayrat et al. (2011a), except that Peronia sp. 2 is sister group to sp. 6. Relationships between Peronia spp. 1-6 are poorly supported and thus remain uncertain.

Pairwise genetic distances for the 69 Peronia sequences corroborate results from our COI tree reconstructions, with support for a clear distinction

Table 1. Intra- and interclade mean (and range of, in parentheses) pairwise genetic distances (uncorrected p-distances, expressed in percentage) calculated using COI sequences from our dataset and Peronia sp. 1-6 sensu Dayrat et al. (2011a) via MEGA 7. Only a single sequence for each of the Peronia sp. 1-6 was made available on GenBank. Hence, where only one sequence was used in the calculation, the uncorrected p-distance is presented as a single value. 30 sequences from our study are grouped with Peronia sp. 2 , while the 33 remaining sequences form a separate clade referred here as Singapore Clade (see Figure 4).

\begin{tabular}{llllllll}
\hline & Sp. 1 & Sp. 2 & Sp. 3 & Sp. 4 & Sp. 5 & Sp. 6 & $\begin{array}{l}\text { Singapore } \\
\text { Clade }\end{array}$ \\
\hline Sp. 1 & - & - & - & - & - & - & - \\
Sp. 2 & $14.03(13.87-14.38)$ & $0.18(0-1.80)$ & - & - & - & - & - \\
Sp. 3 & 14.90 & $10.79(10.62-10.96)$ & - & - & - & - & - \\
Sp. 4 & 15.41 & $6.03(5.99-6.34)$ & 10.10 & - & - & - & - \\
Sp.5 & 15.92 & $6.19(6.16-6.34)$ & 9.76 & 0.86 & - & - & - \\
Sp. 6 & 14.04 & $1.57(1.37-1.88)$ & 10.10 & 6.16 & 6.34 & - & - \\
\hline SC & 15.05 & $5.19(4.65-6.00)$ & 9.93 & 5.36 & 5.53 & 4.52 & 0.22 \\
& $(14.73-15.24)$ & & $(9.59-10.27)$ & $(5.14-5.65)$ & $(5.31-5.82)$ & $(4.11-4.79)$ & $(0-0.75)$ \\
\hline
\end{tabular}



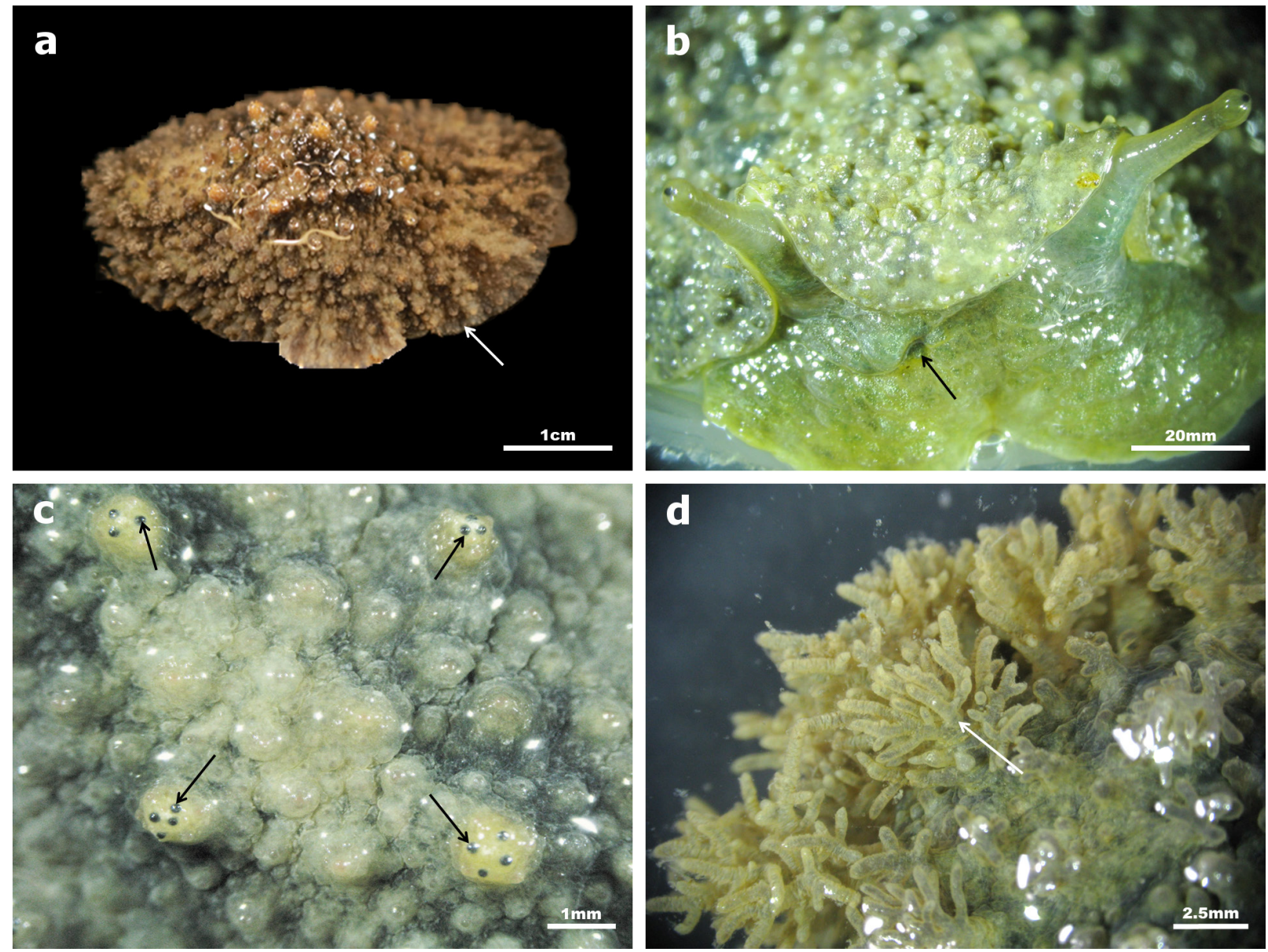

Figure 3. External morphological features present in both Peronia species: (a) ex-situ image of live specimen PV159 (ZRC. MOL.010111), cleaned, dorsal view; white arrow indicates black banding commonly seen on Peronia specimens; (b) anterior view of live specimen, black arrow indicates position of the male genital pore vis-à-vis the ocular tentacles; (c) dorsal eyes (black arrows) on the dorsum of the live specimen; (d) dorsal gills (white arrow), visible when specimen is immersed in seawater. Images (b)-(d) were observed and imaged by mounting Canon Powershot G10 on a Leica S8 APO Stereo Microscope. Images (b)-(d) are not tied to particular voucher numbers but are still included in this paper nonetheless to provide readers a clearer impression of the morphological features of Peronia species.

between Singapore clade and Peronia sp. 2. Interclade distances ranged between $4.7 \%$ and $6.0 \%$, while intraclade genetic distances are fairly low in both Singapore clade and Peronia sp. 2 (maximum of $1.8 \%$; Table 1). In other words, there exists a clear barcoding gap (sensu Meyer and Paulay, 2005) between the intraand interclade genetic distances for the two clades (Figure 5).

\section{External morphology}

The external appearance does not vary consistently amongst individuals and between the two clades containing the P. verruculata-like samples (Peronia sp.
2 and Singapore clade) from Singapore. Dorsal notum colour is highly variable amongst individuals and is difficult to observe in the field as the specimens are often coated with mud or sand grains. Upon cleaning, specimens are either beige mottled with brown-black colouration, or vice versa. Some individuals also have black bands along the notum edges; these bands manifest in a radial fashion like spokes on a wheel from a dorsal perspective (Figure 3a).

The dorsal notum is dotted with tuberculate papillae, which sometimes bear dorsal eyes (in groups of one to four in Peronia sp. 2, and groups of two to nine in the Singapore clade; Figure 3c, Table 2). Dorsal eyes are typically distributed evenly across the anterior and 
Table 2. Comparative external morphology of our specimens from Peronia sp. 2 (30 specimens examined) and Singapore Clade (33 specimens examined). Readers are directed to Figure 3 for images of the morphological features (i.e. male genital pore, dorsal eyes and dorsal gills) used in this comparison. $\mathrm{H}$ and $\mathrm{S}$ refer to hyponotum and sole respectively.

\begin{tabular}{lll}
\hline & Peronia sp. 2 & Singapore Clade \\
\hline Position of male genital pore & Left of the right ocular tentacle & Left of the right ocular tentacle \\
Dorsal eyes & Present, in groups of 1-4 & Present, in groups of 2-9 \\
Dorsal gills & Present, on posterior dorsum & Present, on posterior dorsum \\
Hyponotum $(\mathrm{H})$ and Sole $(\mathrm{S})$ colour & Green & Green \\
H:S ratio & $\mathrm{H}>\mathrm{S}, \mathrm{H}=\mathrm{S}, \mathrm{H}<\mathrm{S}$ & $\mathrm{H}>\mathrm{S}, \mathrm{H}=\mathrm{S}, \mathrm{H}<\mathrm{S}$ \\
\hline
\end{tabular}

middle regions of the dorsal notum. Posteriorly, the dorsal notum is covered with an even distribution of branched papillae, elsewhere referred to as dorsal gills. The gills are typically collapsed when specimens are exposed to the atmosphere but spread out and become erect when immersed (Figure 3d).

Ventrally, the ratio of the hyponotum $(\mathrm{H})$ to pedal sole (S) widths varies across individuals as well as between genetic clusters, with no clear systematic pattern attributable to each clade (Table 2). Both the pedal sole and the hyponotum are green in all specimens.

Anteriorly, the ocular tentacles are superior to the left and right oral lobes as well as the mouth. The ocular tentacles are stubby (as opposed to long and thin in Onchidium typhae), and each bear an eye at the tip of the stalk. In preserved specimens, the eye stalks and oral lobes are retracted. The male genital pore is always located to the left of the right ocular tentacle (Figure 3b).

\section{Morphology of male genitalia}

The Peronia male reproductive organ comprises (i) the penial complex, consisting of the penis, penial sheath, deferent duct and retractor muscle, and (ii) the accessory penial gland. Both the penis and accessory gland spine open into the same male genital pore.

(i) Penial anatomy. The penial sheath of both Peronia sp. 2 and Singapore clade is a long straight stalk that protects the penis for its entire length. An insertion of the retractor muscle marks the separation between the penial sheath (and its constituent penis) and the deferent duct (Dayrat, 2010; Dayrat et al., 2016). Deferent ducts across all specimens are highly convoluted. The penis is typically elongated and tube-like, and always possesses a distal portion covered internally with conical hooks. Penile length is consistent between specimens from either clade, measuring $0.9-1.5 \mathrm{~cm}$.

Noticeable differences in penial morphology can be observed between clades, nonetheless. The penis of Peronia sp. $2(\mathrm{n}=6)$ is narrower in diameter vis-à-vis Singapore clade ( $\mathrm{n}=7$; Figures $6 \mathrm{a}-\mathrm{b}$, Table $3)$. Moreover, the length of the distal portion of the penis with hooks (D) also differs markedly between clades: $0.4-0.5 \mathrm{~cm}$ for Peronia sp. 2 and $0.2-0.3 \mathrm{~cm}$ for Singapore clade. Taken together, the length of the proximal portion of the penis without hooks $(\mathrm{P})$, when expressed as a ratio against $\mathrm{D}$, is approximately about $1-2 \times$ in Peronia sp. 2 as compared to $3-4 \times$ in Singapore clade. Hooks cover the distal portion of the penis in both clades, but with approximately 50-90 hooks per $200 \times 200 \mu \mathrm{m}$ area for Peronia sp. 2, and only 30-50 hooks per same area for the Singapore clade (Figures $6 c-d$ ). Both clades are similar in terms of hook diameter and length (Figures 6e-f, Table 3).

(ii) Accessory penial gland. The accessory penial gland comprises regions of varying thickness; the thinner portion tends to be heavily coiled and is often entangled with the deferent duct. Position of the thicker portion of the accessory gland varies; it is typically embedded underneath the gut for Peronia sp. 2, but easily visible on the surface and posterior to the buccal mass for Singapore clade specimens. The accessory gland ends as a stiff, hollow spine that shares the same vestibule as the penis and is protected by a sheath as well. Gland spine length varies across specimens, but both clades $(\mathrm{n}=7$ each) share the same range of 1.5$2.2 \mathrm{~mm}$ (Table 4). Singapore clade individuals tend to possess a noticeably wider diameter at the conical base of the spine compared to Peronia sp. 2 (Figures 7a-b, Table 4). SEM observations reveal that the distal ends of the gland spine are similar in both clades; 
Table 3. Comparative penial anatomy of Peronia sp. 2 (6 specimens examined) and Singapore Clade (7 specimens examined).

\begin{tabular}{lcc}
\hline & Peronia sp. 2 & Singapore Clade \\
\hline Sample size & 6 & 7 \\
Penial width $(\mathrm{mm})$ & $0.06-0.15$ & $0.16-0.35$ \\
Penial length $(\mathrm{cm})$ & $0.9-1.5$ & $0.9-1.4$ \\
Proximal area without hooks $(\mathrm{P} ; \mathrm{cm})$ & $0.5-1.0$ & $0.7-1.1$ \\
Distal area with hooks $(\mathrm{D} ; \mathrm{cm})$ & $0.4-0.5$ & $0.2-0.3$ \\
P/D & $1-2 \times$ & $3-4 \times$ \\
No. of hooks $($ per $200 \times 200 \mu \mathrm{m})$ & $56-94$ & $32-54$ \\
Hook diameter $(\mu \mathrm{m})$ & $13-43$ & $17-33$ \\
Hook length $(\mu \mathrm{m})$ & $23-89$ & $37-66$ \\
\hline
\end{tabular}

Table 4. Comparative accessory gland spine anatomy of our specimens from Peronia sp. 2 and Singapore Clade (7 specimens from each clade were examined).

\begin{tabular}{lcc}
\hline & Peronia sp. 2 & Singapore Clade \\
\hline Spine length $(\mathrm{mm})$ & $1.54-2.16$ & $1.50-2.06$ \\
Conical base diameter $(\mathrm{C} ; \mu \mathrm{m})$ & $113-181$ & $187-267$ \\
Aperture diameter $(\mathrm{A} ; \mu \mathrm{m})$ & $22-28$ & $58-79$ \\
C/A & $5-7 \times$ & $3-4 \times$ \\
\hline
\end{tabular}

the aperture is slightly apical, centered, with a small triangular lip at the opening (Figures $7 \mathrm{c}-\mathrm{d}$ ). While similar in appearance, diameter of the spine aperture in the Singapore clade is much larger $(61-79 \mu \mathrm{m})$ than in Peronia sp. $2(22-28 \mu \mathrm{m})$.

\section{Radula morphology}

The radula is located within two large postero-lateral muscular masses at the anterior portion of the visceral cavity. Due to similarities between the two clades, the description hereon applies to both clades $(\mathrm{n}=10$ each clade). Complete radulae have an inverted heartshaped appearance (Figures 8a-b). Each radula row consists of a rachidian tooth with two half rows of lateral teeth that are similar in size and shape (Figures $8 \mathrm{c}-\mathrm{d}$ ). Radula formulae are variable across specimens (Table 5). The rachidian tooth is always tricuspid; the median cusp is discernible, while the two lateral cusps are rounded and generally inconspicuous (Figures
$8 \mathrm{c}-\mathrm{d})$. Its base, anchored to the radula membrane, is either flat or mildly triangular. The lateral sides of the rachidian tooth always extend from the membrane at an angle, and they are either straight, or mildly convex. Rachidian teeth tend to be smaller than lateral teeth.

Lateral teeth are arranged in two half rows angled at $45^{\circ}$ from the rachidian axis (Figures $8 \mathrm{e}-\mathrm{f}$ ). They are hook-like; the base rises perpendicular to the radula membrane and the hook curves at almost $90^{\circ}$ relative to the base. The shape of the hook is capsule-like with a rounded ending. There is also a pointed cusp on the lateral expansion of the base, which is usually obscured by the hook of the adjacent, outer lateral tooth and only visible when the teeth are further apart. Although the half-rows are angled at $45^{\circ}$, the hooks themselves are straight and run near-parallel to the rachidian axis. Apart from the first two innermost lateral teeth, the lateral teeth tend to be similar in size and shape. 
Table 5. Comparative radula morphology between specimens from Peronia sp. 2 and Singapore Clade (10 specimens from each clade were examined).

\begin{tabular}{|c|c|c|c|c|c|c|}
\hline \multirow[t]{2}{*}{ Specimen No. } & \multirow{2}{*}{$\begin{array}{c}\text { Radula } \\
\text { Rows }\end{array}$} & \multirow{2}{*}{$\begin{array}{c}\text { Rachidian Tooth } \\
\text { Formula }\end{array}$} & \multicolumn{4}{|l|}{ Lateral Teeth } \\
\hline & & & $\begin{array}{l}\text { Base length } \\
\quad(\mu \mathrm{m})\end{array}$ & $\begin{array}{l}\text { Median cusp } \\
\text { length }(\mu \mathrm{m})\end{array}$ & Length $(\mu \mathrm{m})$ & Width $(\mu \mathrm{m})$ \\
\hline \multicolumn{7}{|l|}{ Peronia sp. 2} \\
\hline PV042 & 33 & $67-1-67$ & 52 & 45 & 100 & 29 \\
\hline PV047 & 31 & $51-1-51$ & 52 & 40 & 74 & 31 \\
\hline PV052 & 35 & $69-1-69$ & 64 & 45 & 100 & 29 \\
\hline PV057 & 25 & $71-1-71$ & 57 & 37 & 106 & 34 \\
\hline PV072 & 28 & $65-1-65$ & 67 & 52 & 102 & 36 \\
\hline PV103 & 35 & $56-1-56$ & 45 & 40 & 90 & 31 \\
\hline PV108 & 41 & $53-1-53$ & 48 & 33 & 79 & 29 \\
\hline PV124 & 42 & $56-1-56$ & 55 & 43 & 69 & 26 \\
\hline PV166 & 40 & $74-1-74$ & 67 & 52 & 102 & 33 \\
\hline PV263 & 34 & $54-1-54$ & 53 & 53 & 79 & 24 \\
\hline \multicolumn{7}{|c|}{ Singapore Clade } \\
\hline PV031 & 26 & $53-1-53$ & 50 & 36 & 71 & 24 \\
\hline PV078 & 40 & $66-1-66$ & obscured & obscured & 78 & 24 \\
\hline PV091 & 32 & $62-1-62$ & 56 & 44 & 79 & 31 \\
\hline PV115 & 33 & $55-1-55$ & 60 & 44 & 85 & 27 \\
\hline PV139 & 29 & $64-1-64$ & obscured & obscured & 76 & 24 \\
\hline PV142 & 37 & $70-1-70$ & 50 & 33 & 79 & 24 \\
\hline PV148 & 34 & $73-1-73$ & 56 & 37 & 87 & 29 \\
\hline PV151 & 36 & $68-1-68$ & 55 & 33 & 112 & 26 \\
\hline PV200 & 31 & $67-1-67$ & 54 & 41 & 80 & 26 \\
\hline PV245 & 41 & $82-1-82$ & 52 & 36 & 76 & 26 \\
\hline
\end{tabular}

\section{Discussion}

COI sequencing of Peronia verruculata-like pulmonates in Singapore has revealed two distinct clades separated by a barcoding gap without overlap between intra- and interclade divergences (Figure 5, Table 1). COI tree reconstructions employing three different optimality criteria concur that these two clades are distinct (Figure 4). It is recognised that COI is not directly involved in speciation and is merely indicative of divergence times (Kwong et al., 2012). Nevertheless, the molecular data are consistent with morphological observations revealing that the two clades exhibit anatomical differences in their male genitalia (specifically in P:D and C:A ratios; Tables
3-4). Such noted variation in the male genitalia hints at possible mechanical reproductive isolation between the two clades. The fact that they co-occur in six out of our nine study sites, and yet remain anatomically and genetically distinct (Figs. 4-7, Table 1), suggests that these two clusters are already on different evolutionary trajectories. It thus appears that there is more than one species of $P$. verruculata in Singapore (contra Liow, 1997; Tan and Woo, 2010). As these two clades are phenetically distinct, diagnosable and reciprocally monophyletic, this conclusion is supported by all commonly used species concepts (see Wheeler and Meier, 2000). Furthermore, Peronia is likely to represent yet another case where distinct genitalia combined with genetic data have successfully detected 


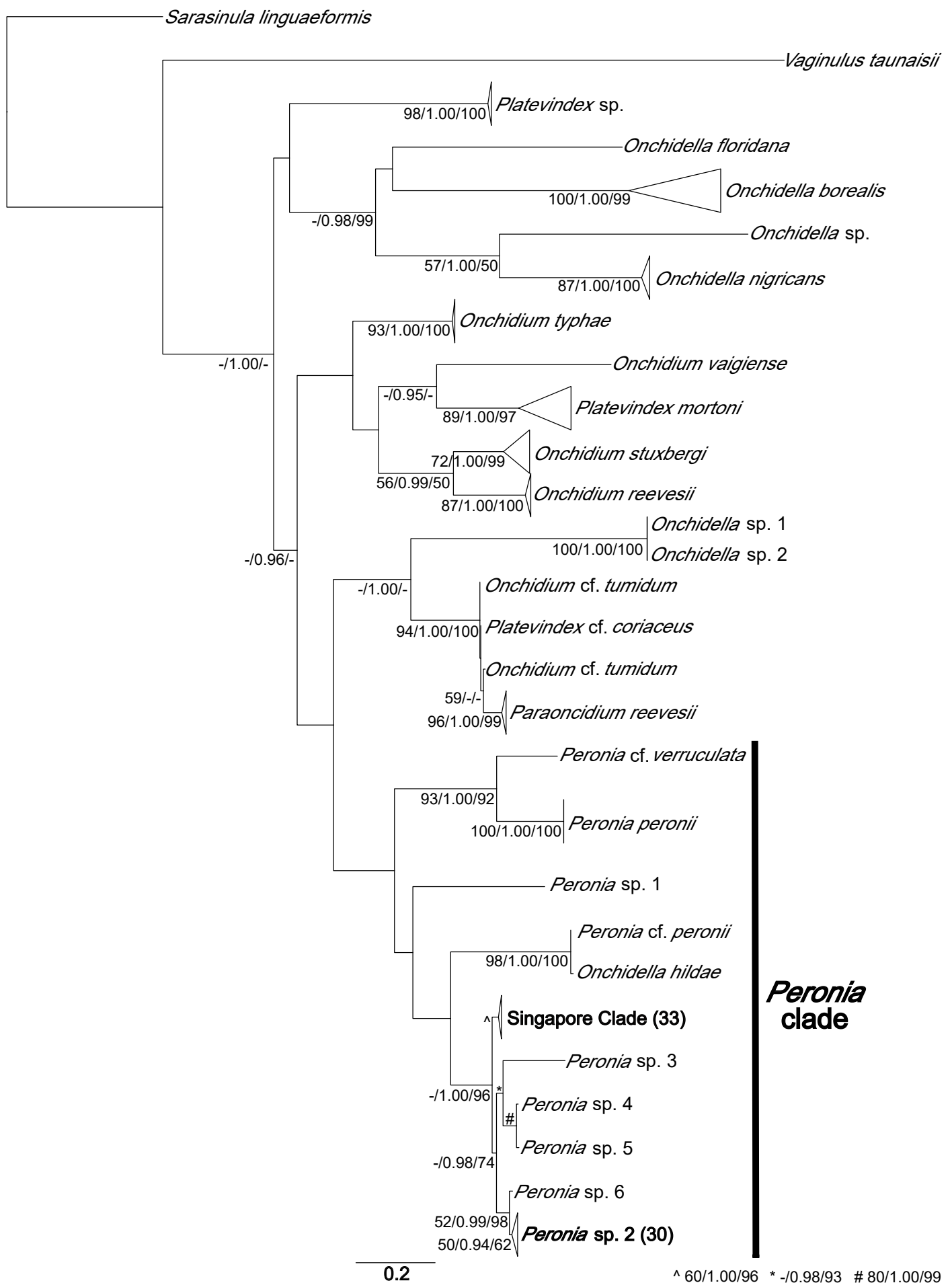

Figure 4. Phylogenetic reconstruction of Onchidiidae based on COI sequences, with Sarasinula linguaeformis and Vaginulus taunaisii as outgroups. Sequences from our own dataset separated into either the Singapore Clade or Peronia sp. 2 (clades are indicated in bold; number of our sequences that separated into each clade are indicated in parentheses). Numbers below branches indicate bootstrap values for maximum likelihood (ML), Bayesian, and maximum parsimony (MP) respectively; only ML bootstrap $>50$, Bayesian posterior probabilities $>0.9$, MP bootstrap $>50$ are reflected on the tree. 


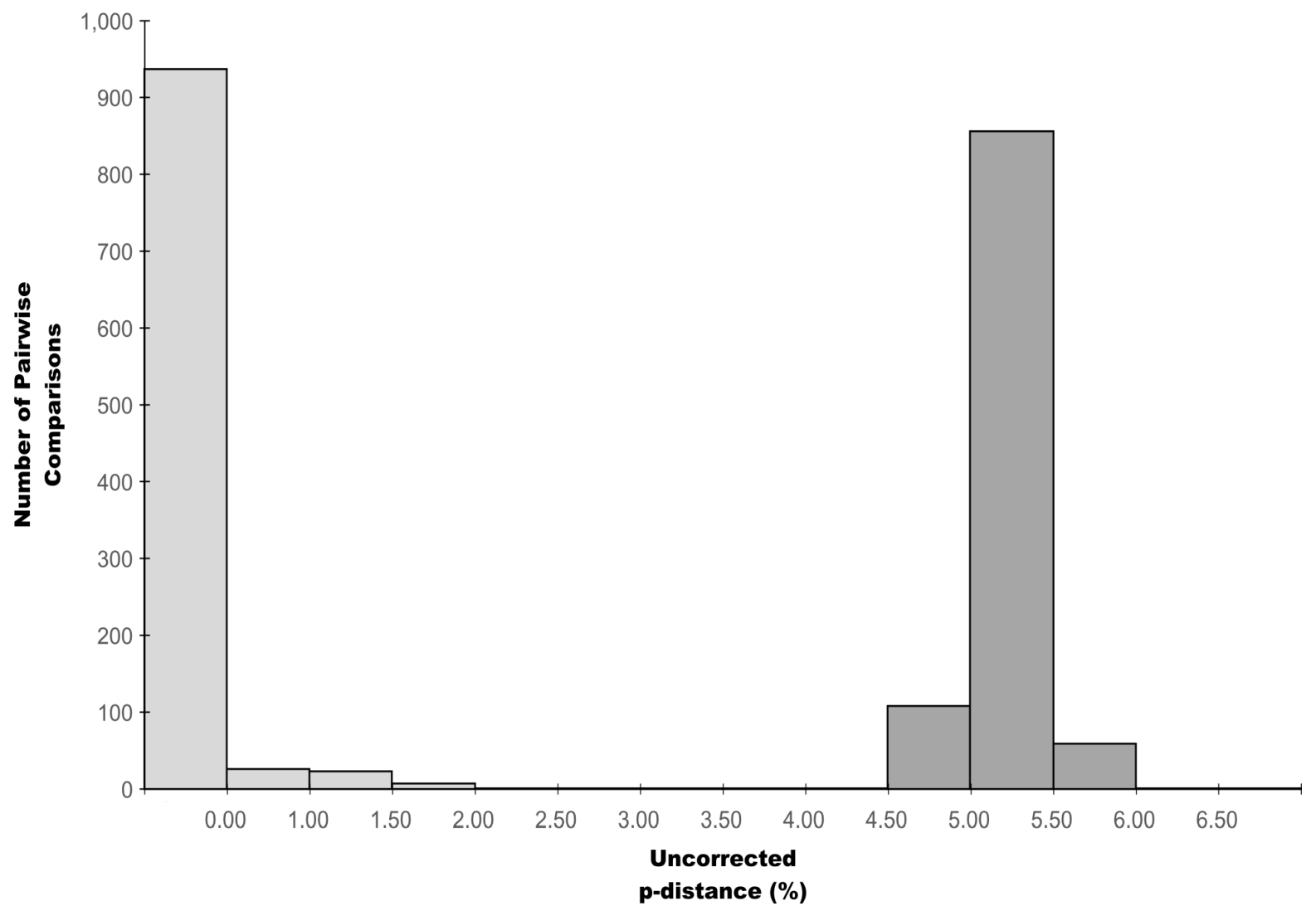

Figure 5. Histogram showing the distribution of pairwise uncorrected p-distances of 63 Peronia sequences from our dataset, obtained via MEGA 7. All intraclade genetic distances (light grey) are below 2.0\%, and all interclade distances (dark grey) are minimally $4.5 \%$ and as high as 6.0\%. A clear and unambiguous barcode gap (sensu Meyer and Paulay, 2005) between 2.0 and $4.5 \%$ is present.

and helped resolve a gastropod species complex (see also Satsuma (Kameda et al., 2007), Bullidae (Malaquias and Reid, 2008), Mandarina (Chiba and Davison, 2008), Leptaxinae (Jordaens et al., 2009), Pseudamnicola (Delicado and Ramos, 2012), Aiteng (Neusser et al., 2011), and Anteaeolidiella (Carmona et al., 2014)).

However, several challenges hamper identification of these Peronia onchidiid clades to species. Cuvier (1830: 46) named $P$. verruculata based on illustrations in Savigny's (1817) Description de l'Egypte (the latter did not provide any species names in his publication; Dayrat, 2009). Unfortunately, Cuvier (1830) did not furnish a description to accompany the name (Dayrat, 2009). As we have also shown, traits proposed by Britton (1984) are of little value as they overlap between both clades and are more appropriate for narrowing down onchidiids to genus rather than species level. The status of the type specimen remains unclear as well (Dayrat, 2009). We were also unable to sample from the type locality of $P$. verruculata in the Red Sea (Dayrat, 2005, 2009), nor the waters surrounding Singapore. While no taxonomic decisions are made here, it is worth noting that the name Onchidium griseo-fuscum (Tapperone-Canefri, 1874), nomen dubium, was established with Singapore as the type locality. Dayrat et al. (2016) suggested the name might belong to Peronia, and thus could be reestablished in future revisions for these Singapore clade onchidiids. Furthermore, the status of Peronia sp. 2 remains unclear as well. Apart from sequence data and locality (Oman), no other information was provided by Dayrat et al. (2011a), curbing further investigative work on this species. It thus remains difficult to assign precise names to these onchidiids as it is impossible to ascertain if they are new to science.

Identification problems remain a pertinent stumbling block in natural history research (Tewksbury et al., 2014), and is especially severe in the tropics where species diversity is high. Yet most species remain undescribed because old descriptions are so superficial that they cannot be used for comparisons (Dayrat et 


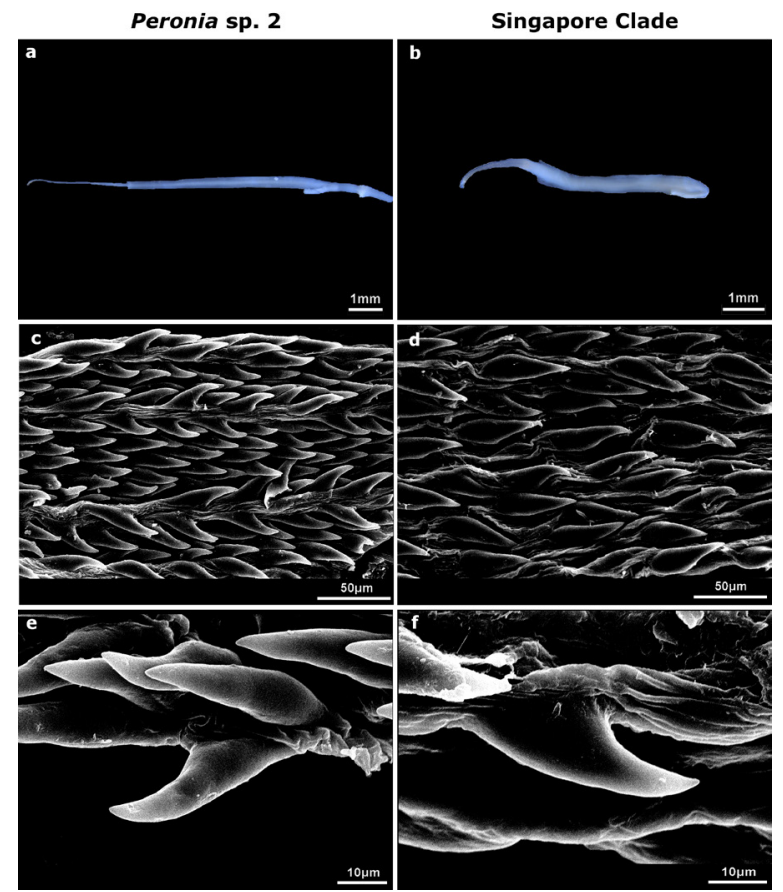

Figure 6. Comparative morphology of penial anatomy, visualised under Leica M205C stereo microscope and SEM. (a), (c), (e) are from our specimens that grouped with Peronia sp. 2 sensu Dayrat et al. (2011a); (b), (d), (f) are from the Singapore Clade. (a) Penis, general view, PV108 (ZRC.MOL.010103). (b) Penis, general view, PV105 (ZRC.MOL.010102). (c) Penial hooks, PV108. (d) Penial hooks, PV068 (ZRC.MOL.010101). (e) Penial hook, PV166 (ZRC.MOL.010111). (f) Penial hook, PV068.

al., 2016, 2017; Meier, 2017). The way forward would undoubtedly be better quality (re)descriptions with high-resolution imaging techniques like SEM (Dayrat, 2010a, 2010b; Dayrat et al., 2011b), complemented with DNA barcodes (Hebert et al., 2003; Dayrat et al., 2016, 2017). The latter is becoming more costefficient (Meier et al., 2016), and will undoubtedly be more prevalent in taxonomic studies. Furthermore, the availability of more genome-wide molecular markers could help reduce uncertainty of phylogenetic relationships amongst Peronia species and advance our understanding of Onchidiidae in relation to other higher pulmonate taxa (Dayrat et al., 2001, 2011a; Vonnemann et al., 2005; Wägele et al., 2014).

The present study has tested a suite of anatomical characters amongst clades of closely related onchidiids. Specifically, we evaluated the potential of the male genitalia (consisting of the penis and the accessory penial gland) and radula in distinguishing onchidiid species. The reproductive system, especially

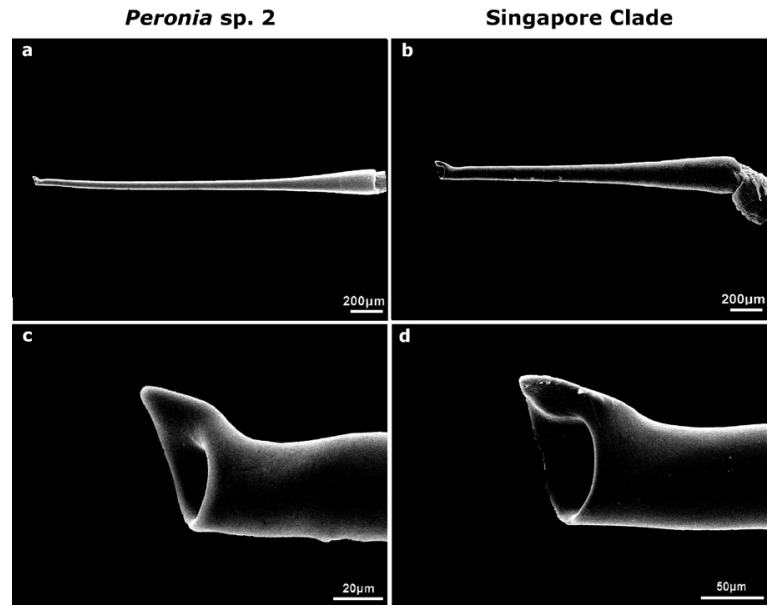

Figure 7. Comparative morphology of the accessory spine gland under SEM. (a) and (c) are from our specimens that grouped with Peronia sp. 2 sensu Dayrat et al. (2011a); (b) and (d) are from the Singapore Clade. (a) Accessory gland spine, general view, PV042 (ZRC.MOL.010099). (b) Accessory gland spine, general view, PV148 (ZRC.MOL.010108). (c) Spine aperture, PV042. (d) Spine aperture, PV148.
Peronia sp. 2
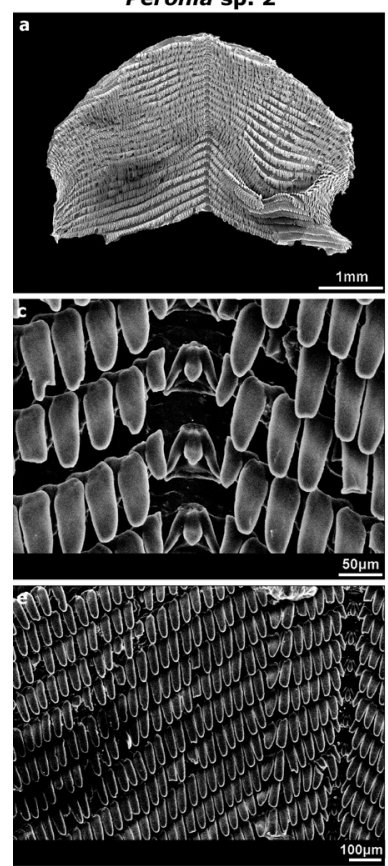

Singapore Clade
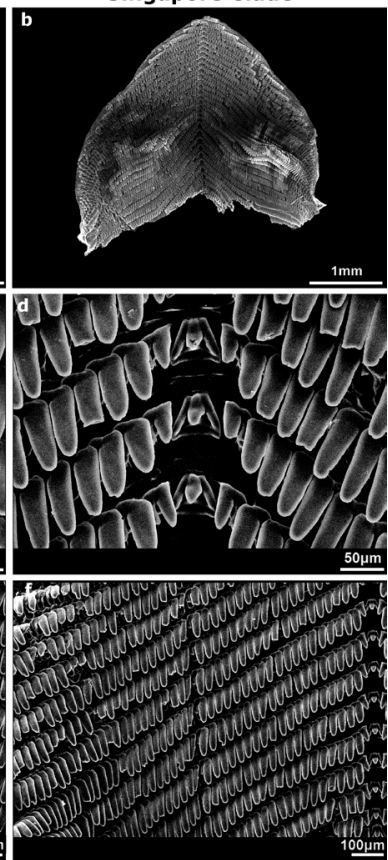

Figure 8. Comparative morphology of radula under SEM. (a), (c), (e) are from our specimens that grouped Peronia sp. 2 sensu Dayrat et al. (2011a); (b), (d), (f) are from the Singapore Clade. (a) Radula, complete, PV072 (ZRC.MOL.010103). (b) Radula, complete, PV200 (ZRC.MOL.010115). (c) Rachidian teeth and innermost lateral teeth, PV166 (ZRC.MOL.010111). (d) Rachidian teeth and innermost lateral teeth, PV151 (ZRC. MOL.010108). (e) Rachidian teeth and lateral teeth, PV103 (ZRC.MOL.010103). (f) Rachidian teeth and lateral teeth, PV142 (ZRC.MOL.010106). 
the anterior male copulatory complex, is of great importance in onchidiid systematics and has long been applied by onchidiid taxonomists (e.g. Labbé, 1934, Starobogatov, 1976, in Dayrat, 2009). Traits that have been studied include the position of the male reproductive aperture vis-à-vis the ocular tentacles, the presence of a full-fledged penis that may or may not be covered with internal hooks, and morphology of the hooks themselves (Dayrat, 2010a; Dayrat, 2010b, $2011 b, 2016$, 2017). While useful for identifying higher taxa, these traits are insufficient in distinguishing the two Peronia clades present in Singapore.

Instead, our detailed measurements on the dimensions of the penis and accessory gland spine detected other informative characters (Tables 3-4). For several onchidiid genera, male copulatory complexes are characterised by accessory penial glands. Like the penis, presence of the penial gland and morphology of the spine aperture vary between genera (Dayrat, 2010a, 2010b; Dayrat et al., 2011b, 2016, 2017). Observations here reveal that the overall morphology of the spine gland is invariable amongst Peronia species (Figure 7), but there are differences in dimensions and proportions of the structure between Peronia sp. 2 and Singapore clade (Table 4). We suggest that a morphometric approach applied to genitalia anatomy has potential for detecting morphological differences between closely-related onchidiid species.

The radula formula was not useful in distinguishing the two Peronia clades, largely due to its high variability. Our results not only mirror findings from Bertsch (1976), who noted intraspecific radula plasticity within gastropods, but also lend support to claims that radula morphology might be similar amongst closely related onchidiid species (Dayrat, 2010a, 2010b; Dayrat et al., 2017). The radula formula is thus ineffective for species delimitation. Nevertheless, radula morphology and formula might be useful for comparisons between genera as more SEM data become available. For example, the lateral teeth of Peronia specimens are straight and near-parallel to the rachidian axis, as opposed to those in Semperoncis montana and Platevindex mortoni, which are spatulate and tend to curve inward (Dayrat, 2010a: figs. 15-20; Zhang et al., 2017: fig. 3); or even Melayonchis onchidiids, which have a distinctive protuberance on the inner lateral margin of each lateral tooth that is insofar specific to that genus (Dayrat et al., 2017: figs. 6, 13, 18, 24).

Evidently, external morphology has not been useful in distinguishing members of the Peronia cryptic species complex found in Singapore, unlike that of
Onchidium (Dayrat et al., 2016) or Melayonchis (Dayrat et al., 2017) onchidiids, which do not have overlapping morphologies between species. For instance, foot and dorsal colouration of the live animals is specific to each species of Onchidium and Melayonchis, respectively (Dayrat et al., 2016, 2017), making it easy to identify them. We have demonstrated that distinctive traits of Peronia are present in both members of the genus, and that variations in these traits are not clade-specific, a point echoed by Dayrat et al. (2017).

Given the relatively short branch lengths on the COI tree (Figure 4), Peronia spp. 2-6 sensu Dayrat et al. (2011a) and Singapore clade may constitute a case of adaptive radiation, in which species are only beginning to diverge into separate lineages. Such a radiation would certainly support the prevailing hypothesis that onchidiids originated out of warm, tropical waters (Dayrat et al., 2011a), from which Peronia spp. 1-6 and Singapore clade specimens were obtained. If these species are part of an adaptive radiation, the more interesting task would be to uncover the drivers behind this evolutionary process, which could involve niche differentiation in the form of habitat or resource partitioning (Rundell and Price, 2009). However, more ecological and biogeographical data for onchidiids are needed to test these hypotheses. For instance, future work could explore diets of the two onchidiids in Singapore via faecal metagenomic sequencing (e.g. Srivathsan et al., 2016) to discern if this observed sympatry may be due to resource partitioning or associated with competitive exclusion.

Interestingly, Liow (1997) observed that Onchidium aberrans Semper, 1885 (designated nomen dubium, Dayrat et al., 2016) was not only similar to $P$. verruculata in terms of abundance, but also found to co-occur with $P$. verruculata. This is strikingly similar to what was observed for Singapore clade and Peronia sp. 2. However, Liow's (1997) detailed morphological analysis of $O$. aberrans showed that it did not possess dorsal gills and was thus unlikely to be the Singapore clade onchidiid found in this study. These patterns hint at a possible shift in onchidiid community composition over the years. The LKCNHM Onchidiidae collection was examined, but unfortunately, historical comparisons here with the museum specimens were unfruitful for several reasons. First, most of the specimens were recorded as "Onchidiidae sp." making it difficult to establish past species composition in the absence of DNA barcoding as we were unable to identify them to species level. Second, most specimens were sampled from mangrove habitats which lie 
outside known ranges of Peronia (Liow, 1997; Dayrat et al., 2017); they are unlikely to be Peronia and thus discussion pertaining to the collection as a whole is beyond the scope of this paper. Finally, most of the "Onchidium verruculatum" specimens were sampled from a single site (Punggol). Without DNA barcoding to identify these onchidiids and more localities for comparison, we remain unable to quantify community shifts over time. Clearly, more work is needed to better understand the ecology of these onchidiids.

\section{Conclusion}

In this paper, we complemented DNA sequence information of $P$. verruculata-like specimens from Singapore with SEM data of internal organs to show that they form two closely-related clades with distinct mitochondrial COI signatures and male genitalia measurements. Using this integrative approach, we present evidence that what was initially thought to be $P$. verruculata might be two different members of the genus in Singapore. Owing to the family's complex taxonomic history, and the lack of samples from the type locality, we have opted for a tempered interpretation of our results and chosen not propose formal taxonomic changes. Nonetheless, the provision here of detailed SEM images and data, a first for Peronia to our knowledge, contributes to a better understanding of morphological evolution and reproductive compatibility amongst onchidiid species.

\section{Acknowledgements}

We are immensely grateful to Celestine Shi Le Yee, Diego Pitta de Araujo, Gayathiri D/O Sivananthan, Keay Hoon Pwa, Lynette Shu Min Ying, Mei Lin Neo, Sean Yap, Siti Zarina Zainul Rahim, Suhailah binte Isnin, Yin Cheong Aden Ip, Yong Kit Samuel Chan and Yue Sze for their help with field collections, and also to Roberto Arrigoni for searching for Peronia in the Red Sea. We extend our gratitude to Nicholas Wei Liang Yap for advice on taxonomy and microscopy, Ping Lee Chong for guidance on the scanning electron microscope, Sze Min Charlene Mary-Anne $\mathrm{Ng}$ for laboratory and technical assistance, as well as Siong Kiat Tan, Kok Peng Kelvin Lim, and Khek Yan Lee for museum support. Lee Hsiang Liow is also appreciated for making available her Honours thesis and discussion. Lastly, we thank Bert Hoeksema and two anonymous reviewers, whose comments have helped improve the quality of this manuscript. This research was supported by the National Parks Board (R347-000-242-490) as well as the National Research Foundation, Prime Minister's Office, Singapore under its Marine Science R\&D Programme (MSRDP-P03).

\section{References}

Armstrong KF, Ball SL. 2005. DNA barcodes for biosecurity: invasive species identification. Philosophical Transactions of The Royal Society B 360: 1813-1823.

Awati PR, Karandikar KR. 1948. Onchidium verraculatum (Anatomy, Embryology and Bionomics). Zoological Memories, University of Bombay 1: 1-53.

Bertsch H. 1976. Intraspecific and ontogenetic radular variation in Opisthobranch systematics (Mollusca: Gastropoda). Systematic Biology 25: 117-122.

Bickford D, Lohman DJ, Sodhi NS, Ng PKL, Meier R, Winker K, Ingram KK, Das I. 2007. Cryptic species as a window on diversity and conservation. Trends in Ecology and Evolution 22: 148-155.

Britton KM. 1984. The Onchidiacea (Gastropoda: Pulmonata) of Hong Kong with a worldwide review of the genera. Journal of Molluscan Studies 50: 179-191.

Carmona L, Bhave V, Salunkhe R, Pola M, Gosliner TM, Cervera JL. 2014. Systematic review of Anteaeolidiella (Mollusca: Nudibranchia: Aeolidiidae) based on morphological and molecular data, with a description of three new species. Zoological Journal of the Linnean Society 171: 108-132.

Chiba S, Davison A. 2008. Anatomical and molecular studies reveal several cryptic species of the endemic genus Mandarina (Pulmonata: Helicoidea) in the Ogasawara Islands. Journal of Molluscan Studies 74: 373-382.

Cumming RA. 2013. Evolutionary biogeography and patterns of dispersal in the intertidal slug Onchidella (Systellomatophora: Mollusca): 1-168 (Unpublished Ph.D. thesis, University of Otago, New Zealand).

Cuvier G. 1830. Le Règne Animal, nouvelle édition. Volume 3, xvi + 504 pp., 20 pls. Déterville, Paris.

Darriba D, Taboada GL, Doallo R, Posada D. 2012. jModelTest 2: more models, new heuristics and high-performance computing. Nature Methods 9: 772.

Dayrat B. 2005. Towards integrative taxonomy. Biological Journal of the Linnean Society 85: 407-415.

Dayrat B. 2009. Review of the current knowledge of the systematics of Onchidiidae (Mollusca: Gastropoda: Pulmonata) with a checklist of nominal species. Zootaxa 2068: 1-26.

Dayrat B. 2010a. Anatomical re-description of the terrestrial onchidiid slug Semperoncis montana (Plate, 1893). Malacologia 52: 1-20.

Dayrat B. 2010b. Comparative anatomy and taxonomy of $\mathrm{On}$ chidium vaigiense (Gastropoda: Pulmonata: Onchidiidae). Journal of Molluscan Research 30: 87-101.

Dayrat B, Tillier A, Lecointre G, Tillier S. 2001. New clades of euthyneuran gastropods (Mollusca) from rRNA sequences. Molecular Phylogenetics and Evolution 19: 225-235.

Dayrat B, Conrad M, Balayan S, White TR, Albrecht C, Golding R, Gomes SR, Harasewych MG, Martins AMF. 2011a. Phylogenetic relationships and evolution of pulmonate gastropods (Mollusca): new insights from increased taxon sampling. Molecular Phylogenetics and Evolution 59: 425-437.

Dayrat B, Zimmermann S, Raposa M. 2011b. Taxonomic revision of the Onchidiidae (Mollusca: Pulmonata) from the Tropical Eastern Pacific. Journal of Natural History 45: 9391003.

Dayrat B, Goulding TC, Apte D, Bhave V, Comendador J, Quang NX, Tan SK, Tan SH. 2016. Integrative taxonomy of the ge- 
nus Onchidium Buchannan, 1800 (Mollusca: Pulmonata: Onchidiidae). ZooKeys 636: 1-40.

Dayrat B, Goulding TC, Apte D, Bhave V, Quang NX. 2017. A new genus and four new species of onchidiid slugs from South-East Asia (Mollusca: Gastropoda: Pulmonata: Onchidiidae). Journal of Natural History 51: 1-47.

Delicado D, Ramos MA. 2012. Morphological and molecular evidence for cryptic species of springsnails [genus Pseudamnicola (Corrosella) (Mollusca: Caenogastropoda: Hydrobiidae)]. ZooKeys 190: 55-79.

Folmer O, Black M, Hoeh W, Lutz R, Vrijenhoek R. 1994. DNA primers for amplification of mitochondrial cytochrome $c$ oxidase subunit I from diverse metazoan invertebrates. Molecular Marine Biology and Biotechnology 3: 294-299.

Goloboff PA, Farris JS, Nixon KC. 2008. TNT, a free program for phylogenetic analysis. Cladistics 24: 774-786.

Hajibabaei M, Singer GAC, Hebert PDN, Hickey DA. 2007. DNA barcoding: how it complements taxonomy, molecular phylogenetics and population genomics. Trends in Genetics 23: 167-172.

Hebert PDN, Gregory TR. 2005. The promise of DNA barcoding for taxonomy. Systematic Biology 54: 852-859

Hebert PDN, Cywinska A, Ball SL, deWaard JR. 2003. Biological identifications through DNA barcodes. Philosophical Transactions of the Royal Society of London B: Biological Sciences 270: 313-321.

Hebert PDN, Penton EH, Burns JM, Janzen DH, Hallwachs W. 2004. Ten species in one: DNA barcoding reveals cryptic species in the neotropical skipper butterfly Astraptes fulgerator. Proceedings of the National Academy Sciences 101: 14812-14817.

Hendrixson BE, Guice AV, Bond JE. 2015. Integrative species delimitation and conservation of tarantulas (Araneae: Mygalomorphae: Theraphosidae) from a North American biodiversity hotspot. Insect Conservation and Diversity 8: 120131.

Johnson MS, Stankowski S, Kendrick PG, Hamilton ZR, Teale RJ. 2016. Diversity, complementary distributions and taxonomy of Rhagada land snails (Gastropoda: Camaenidae) on the Burrup Peninsula, Western Australia. Invertebrate Systematics 30: 323-334.

Johnson SB, Waren A, Vrijenhoek RC. 2008. DNA barcoding of Lepetodrilus limpets reveals cryptic species. Journal of Shellfish Research 27: 43-51.

Jordaens K, Riel PV, Martins AMF, Backeljau T. 2009. Speciation on the Azores islands: congruent patterns in shell morphology, genital anatomy, and molecular markers in endemic and snails (Gastropoda: Leptaxinae). Biological Journal of Linnean Society 97: 166-176.

Kameda Y, Kawakita A, Kato M. 2007. Cryptic genetic divergence and associated morphological differentiation in the arboreal land snail Satsuma (Luchuhadra) largillierti (Camaenidae) endemic to the Ryukyu Archipelago, Japan. Molecular Phylogenetics and Evolution 45: 519-533.

Katoh K, Standley DM. 2013. MAFFT multiple sequence alignment software version 7: Improvements in performance and usability. Molecular Biology and Evolution 30: 772780.

Katoh K, Toh H. 2008. Recent developments in the MAFFT multiple sequence alignment program. Briefings in Bioinformatics 9: 286298.

Katoh K, Misawa K, Kuma K, Miyata T. 2002. MAFFT: a novel method for rapid multiple sequence alignment based on fast Fourier transform. Nucleic Acids Research 30: 30593066.

Kearse M, Moir R, Wilson A, Stones-Havas S, Cheung M, Sturrock S, Buxton S, Cooper A, Markowitz S, Duran C, Thierer T, Ashton B, Mentjies P, Drummond A. 2012. Geneious Basic: An integrated and extendable desktop software platform for the organization and analysis of sequence data. Bioinformatics 28: 1647-1649.

Kress WJ, Garcia-Robledo C, Uriarte M, Erickson DL. 2015. DNA barcodes for ecology, evolution, and conservation. Trends in Ecology and Evolution 30: 25-35.

Kumar S, Stecher G, Tamura K. 2016. MEGA 7: Molecular Evolutionary Genetics Analysis version 7.0 for bigger datasets. Molecular Biology and Evolution 33: 1870-1874.

Kwong S, Srivathsan A, Meier R. 2012. An update on DNA barcoding: low species coverage and numerous unidentified sequences. Cladistics 28: 639-644.

Labbé A. 1934. Les Silicodermés (Labbé) du Muséum d'Histoire Naturelle de Paris. Première partie: Classification, forms nouvelles ou peu connues. Annales de l'Institut Océanographique de Monaco 14: 173-246.

Lai S, Loke LHL, Hilton MJ, Bouma TJ, Todd PA. 2015. The effects of urbanization on coastal habitats and the potential for ecological engineering: A Singapore case study. Ocean and Coastal Management 103: 78-85.

Lawler AJ, Duda Jr. TF. 2017. Molecular and morphometric data suggest the presence of a neglected species in the marine gastropod family Conidae. Molecular Phylogenetics and Evolution 109: 421-429.

Layton KKS, Martel AL, Hebert PDN. 2014. Patterns of DNA barcode variation in Canadian marine molluscs. PLOS ONE 9: e95003.

Layton KKS, Gosliner TM, Wilson NG. 2018. Flexible colour patterns obscure identification and mimicry in Indo-Pacific Chromodoris nudibranchs (Gastropoda: Chromodorididae). Molecular Phylogenetics and Evolution 124: 27-36.

Liow LH. 1997. Singapore Onchidiidae (Mollusca: Pulmonata) An attempt at phylogenetic analysis using anatomical and allozyme data: 1-85 (Unpublished honours thesis, National University of Singapore, Singapore).

Liu C, Wei L, Shen H, Zhu HC, Zhou N. 2014. Complete mitochondrial genome of Peronia verruculata (Gastropoda: Pulmonata: Systellommatophora: Onchidiidae). Mitochondrial DNA 26: 753-754.

Lundin K, Korshunova T, Malmberg K, Martynov A. 2017. Intersection of historical museum collections and modern systematics: a relict population of the Arctic nudibranch Dendronotus velifer G. O. Sars, 1878 in a Swedish fjord. Contributions to Zoology 84: 303-318.

Mace GM. 2004. The role of taxonomy in species conservation. Philosophical Transactions of the Royal Society of London B: Biological Sciences 359: 711-719.

Maddison WP, Maddison DR. 2017. Mesquite: A modular system for evolutionary analysis (Version 3.20). URL: http:// mesquiteproject.org

Malaquias MAE, Reid DG. 2008. Systematic revision of the living species of Bullidae (Mollusca: Gastropoda: Cephalaspidea), with a molecular phylogenetic analysis. Zoological Journal of the Linnean Society 153: 453-543.

McFarlane I. 1980. Trail-following and trail-searching behaviour in homing of the intertidal gastropod mollusc, Onchidi- 
um verruculatum. Marine Behaviour and Physiology 7: 95108.

McFarlane I. 1981. In the intertidal homing gastropod Onchidium verruculatum (Cuv.) the outward and homeward trails have a different information content. Journal of Experimental Marine Biology and Ecology 51: 207-218.

Meier R. 2017. Citation of taxonomic publications: the why, when, what and what not. Systematic Entomology 42: 301304.

Meier R, Kwok S, Vaidya G, Ng PKL. 2006. DNA barcoding and taxonomy in Diptera: a tale of high intraspecific variability and low identification success. Systematic Biology 55: 715728.

Meier R, Wong W, Srivathsan A, Foo M. 2016. \$1 DNA barcodes for reconstructing complex phenomes and finding rare species in specimen-rich samples. Cladistics 32: 100-110.

Meyer CP, Paulay G. 2005. DNA barcoding: error rates based on comprehensive sampling. PLoS Biology 3: 2229-2238.

Meyers-Muñoz MA, van der Velde G, van der Meij SET, Stoffels BEMW, van Alen T, Tuti Y, Hoeksema BW. 2016. The phylogenetic position of a new species of Plakobranchus from West Papua, Indonesia (Mollusca, Opisthobranchia, Sacoglossa). ZooKeys 594: 73-98.

MolluscaBase. 2018. Onchidiidae Rafinesque, 1815. Accessed through: World Register of Marine Species at: http://marinespecies.org/aphia.php? $\mathrm{p}=$ taxdetails $\& i d=1773$ on 201805-13

Moura CJ, Harris DJ, Cunha MR, Rogers AD. 2008. DNA barcoding reveals cryptic diversity in marine hydroids (Cnidaria: Hydrozoa) from coastal and deep-sea environments. Zoologica Scripta 37: 93-108.

Neusser TP, Fukuda H, Jorger KM, Kano Y, Schrodl M. 2011. Sacoglossa or Acochlidia? 3D reconstruction, molecular phylogeny and evolution of Aitengidae (Gastropoda: Heterobranchia). Journal of Molluscan Studies 77: 332-350.

Pons J, Barraclough TG, Gomez-Zurita J, Cardoso A, Duran DP, Hazell S, Kamoun S, Sumlin WD, Vogler AP. 2006 Sequence-based species delimitation for the DNA taxonomy of undescribed insects. Systematic Biology 55: 595-609.

Rambaut A, Suchard MA, Xie D, Drummond AJ. 2014. Tracer: MCMC Trace Analysis Tool. Version 1.6.

Ronquist F, Teslenko M, van der Mark P, Ayres DL, Darling A, Höhna S, Larget B, Liu L, Suchard MA, Huelsenbeck JP. 2012. MrBayes 3.2: efficient Bayesian phylogenetic inference and model choice across a large model space. Systematic Biology 61: 539-542.

Rundell RJ, Price TD. 2009. Adaptive radiation, nonadaptive radiation, ecological speciation and nonecological speciation. Trends in Ecology and Evolution 24: 394-399.

Savigny JC. 1817. Description de l'Égypte, ou Recueil des observation et des recherches qui ont été faites en Égypte pendant l'Expédition de l'Armée française publié par ordre du Gouvernement. Histoire Naturelle, planches, Tome Deuxième. Paris, Imprimerie Royale, 105 pls.

Semper C. 1885. Dritte Familie, Onchidiidae. In: Semper C (Ed.) Reisen im Archipel der Philippinen, Wissenschaftliche Resultate, III (7). C.W. Kreidel, Wiesbaden, 251-290. [pl. XIX-XXVII]

Srivathsan A, Meier R. 2012. On the inappropriate use of Kimura-2-parameter (K2P) divergences in the DNA-barcoding literature. Cladistics 28: 190-194.
Srivathsan A, Ang A, Vogler AP, Meier R. 2016. Faecal metagenomics for the simultaneous assessment of diet, parasites, and population genetics of an understudied primate. Frontiers in Zoology 13: 1-17.

Stamatakis A. 2006. RAxML-VI-HPC: maximum likelihoodbased phylogenetic analyses with thousands of taxa and mixed models. Bioinformatics 22: 2688-2690.

Stamatakis A. 2014. RAxML version 8: a tool for phylogenetic analysis and post-analysis of large phylogenies. Bioinformatics 30: 1312-1313.

Stamatakis A, Hoover P, Rougemont J. 2008. A rapid bootstrap algorithm for RAxML Web servers. Systematic Biology 57: 758-771.

Stoffels BEMW, van der Meij SET, Hoeksema BW, van Alphen J, van Alen T, Meyers-Muñoz MA, de Voogd NJ, Tuti Y, van der Velde G. 2016. Phylogenetic relationships within the Phyllidiidae (Opisthobranchia, Nudibranchia). ZooKeys 605: 1-35.

Sun B, Chen C, Shen H, Zhang K, Zhou N, Qian J. 2014. Species diversity of Onchidiidae (Eupulmonata: Heterobranchia) on the mainland of China based on molecular data. Journal of Molluscan Research 34: 62-70.

Tan DSH, Ang Y, Lim GS, Ismail MRB, Meier R. 2010. From "cryptic species" to integrative taxonomy: an iterative process involving DNA sequences, morphology, and behaviour leads to the resurrection of Sepsis pyrrhosoma (Sepsidae: Diptera). Zoologica Scripta 39: 51-61.

Tan KS, Acerbi E, Lauro FM. 2016. Marine habitats and biodiversity of Singapore's coastal waters: A review. Regional Studies in Marine Science 8: 340-352.

Tan SK, Woo HPM. 2010. A preliminary checklist of the molluscs of Singapore. Raffles Museum of Biodiversity Research, National University of Singapore, 76 pp.

Tapparone-Canefri C. 1874. Zoologia del viaggio intorno al globo della regia fregata Magenta duranto gli anni 1865-68. Malacologia (Gastropodi, Acefali e Brachiopodi). Paravia, Torino, $152 \mathrm{pp}$.

Tewksbury JJ, Anderson JGT, Bakker JD, Billo TJ, Dunwiddie PW, Groom MJ, Hampton SE, Herman SG, Levey DJ, Machnicki NJ, del Rio CM, Power ME, Rowell K, Salomon AK, Stacey L, Trombulak SC, Wheeler TA. 2014. Natural history's place in Science and Society. Bioscience 64: 300-310.

Todd PA, Chou LM. 2005. A tale of survival: Labrador Park, Singapore. Coral Reefs 24: 391.

Vogler AP, Monaghan MT. 2007. Recent advances in DNA taxonomy. Journal of Zoological Systematics and Evolutionary Research 45: 1-10.

Vonnemann V, Schrödl M, Klussmann-Kolb A, Wägele H. 2005. Reconstruction of the phylogeny of the Opisthobranchia (Mollusca: Gastropoda) by means of 18 s and 28s rRNA gene sequences. Journal of Molluscan Studies 71: 113-125.

Wägele H, Klussmann-Kolb A, Verbeek E, Schrödl M. 2014. Flashback and foreshadowing - a review of the taxon Opisthobranchia. Organisms Diversity and Evolution 14: 133-149.

Weigand AM, Jochum A, Pfenninger M, Steinke D, KlussmannKolb A. 2011. A new approach to an old conundrum - DNA barcoding sheds new light on phenotypic plasticity and morphological stasis in microsnails (Gastropoda: Pulmonata: Carychiidae). Molecular Ecology Resources 11: 255-265.

Wheeler QD, Meier R (Eds). 2000. Species Concepts and Phy- 
logenetic Theory: A Debate. Columbia University Press, $256 \mathrm{pp}$.

White TR, Conrad MM, Tseng R, Balayan S, Golding R, Martins AMF, Dayrat, B. 2011. Ten new complete mitochondrial genomes of pulmonates (Mollusca: Gastropoda) and their impact on phylogenetic relationships. BMC Evolutionary Biology 11: 1-15.

Will KW, Mishler BD, Wheeler QD. 2005. The perils of DNA barcoding and the need for integrative taxonomy. Systematic Biology 54: 844-851.

Witt JDS, Threloff DL, Hebert PDN. 2006. DNA barcoding reveals extraordinary cryptic diversity in an amphipod genus: implications for desert spring conservation. Molecular Ecology 15: 3073-3082.

Zhang K, Wang D, Shen H, Qian J, Guan J, Wu H, Gao Y. 2017. Redescription of Platevindex mortoni (Gastropoda: Eupulmonata: Onchidiidae) from China. Molluscan Research 37: $72-78$.

Zhou N, Shen H, Chen C, Sun B, Zheng P, Wang C. 2016. Genetic structure of Onchidium "struma" (Mollusca: Gastropoda: Eupulmonata) from the coastal area of China based on mtCOI, Mitochondrial DNA Part A 27: 1319-1323.

Received: 1 March 2018

Revised and accepted: 30 May 2018

Published online: 20 September 2018

Editor: B.W. Hoeksema

\section{Online supplementary information}

S1. List of Peronia specimens in this study. 